Gulawentah: Jurnal Studi Sosial

ISSN 2528-6293 (Print); ISSN 2528-6871 (Online)

Vol. 4, No. 1, Juli 2019, Hal 56-66

Tersedia Online: http://e-journal.unipma.ac.id/index.php/gulawentah

\title{
Rekonstruksi Rumah Majapahit di Desa Bejijong Sebagai Sarana Edukasi Pendidikan IPS
}

\author{
Sugiyono Ruslan \\ PGSD, Universitas Muhamadiyah Surabaya, Indonesia \\ Email: ruslansugiono@yahoo.co.id
}

\begin{abstract}
Abstrak
Tujuan penelitian ini yaitu ntuk mendeskripsikan rekonstruksi rumah masa kerajaan Majapahit di desa Bejijong kecamatan Trowulan Mojokerto dijadikan sebagai pengayaan bahan ajar mata kuliah pendidikan IPS bagi mahasiswa program S1 PGSD dan menganalisis tentang rumah masa kerajaan Majapahit sebagai bahan ajar mata kuliah Pendidikan IPS. Pendekatan penelitian yang digunakan adalah pendekatan kualitatif yaitu berpikir secara induktif memandang masalah penelitian sebagai kasus yang bersifat mikro, kemudian ditarik dalam konteks yang lebih umum. Jenis penelitian yang digunakan adalah studi kasus. Peneliti terlibat langsung dalam penelitian dan tidak diwakilkan, dalam pelaksanaan penelitian ini peneliti melakukan interaksi secara intensif dengan subjek penelitian. Jenis data penelitian secara empiris, yaitu data apa adanya yang terjadi di lapangan tanpa memberi arti makna dibalik peristiwa, dengan sumber data baik sumber data primer maupun sumber data sekunder kepada informan kunci menggunakan teknik nonprobability sampling jenis purposive sampling dan snowball sampling. Dari penelitian yang telah dilakukan dapat disampaikan bahwa rekonstruksi rumah Majapahit di desa Bejijong Kecamatan Trowulan Mojokerto merupakan bentuk penggugah semangat masyarakat Indonesia akan kebesaran suatu bangsa dari sejarah di masa lampau, yang dapat dijadikan sebagai pengayaan bahan ajar baik di pendidikan tingkat dasar sampai perguruan tinggi, walaupun bentuk rumah yang ditampilkan belum mencerminkan secara utuh rumah Majapahit disebabkan banyaknya bentuk rumah yang beraneka ragam berdasarkan tingkat/strata masyarakat Majapahit. Dengan demikian rekonstruksi rumah masa kerajaan Majapahit di desa Bejijong kecamatan Trowulan Mojokerto sangat berpotensi untuk dijadikan pengayaan bahan ajar mata kuliah pendidikan IPS bagi mahasiswa program SI PGSD khususnya pada standar kemampuan/kompetensi akhir yang direncanakan yaitu memahami komponen perencanaan pembelajaran IPS dengan materi pokok komponen perencanaan pembelajaran IPS.
\end{abstract}

Kata kunci: Rumah Majapahit; Bahan Ajar; Pendidikan IPS PGSD

\section{The Reconstruction of Majapahit Era House in Bejujong Village as Education Media For Social Education Knowledge (IPS)}

\begin{abstract}
The purpose of this research is to describe the reconstruction towards the Majapahit age house in Bejijong Village at Trowulan District inside Mojokerto City as an enrichment for teaching material college subject for social education knowledge towards colleger taking S1 PGSD program and to analyze about the Majapahit kingdom era house as a teaching material IPS education. The research approach used is a qualitative approach that is to think inductively view the research problem as a micro case, then drawn in a more general context. The type of research used is a case study. Researchers are directly involved in the research and not represented, in the implementation of this study researchers conducted an intensive interaction with the subject of research.The type of data is empirically research that is reality data in the field without giving meaning to the behind the event, with data sources both primary data sources and secondary dara sources to key informants
\end{abstract}

DOI: 10.25273/gulawentah.v4i1.5033

Copyright (C) 2019 Universitas PGRI Madiun

All rights reserved. 
using nonprobability sampling techniques of purposive sampling and snowball sampling. From the research that has been done, it can be conveyed that the reconstruction of the Majapahit house in Bejijong village, Trowulan Mojokerto Subdistrict is a form of inspiring the spirit of the Indonesian people for the greatness of a nation from history, which can be used as the enrichment of teaching materials both in elementary to university education, although the form of the house that is displayed not reflect intact Majapahit house due to the many forms of homes are diverse based on the level I strata Majapahit society. The reconstruction towards the Majapahit house in Bejijong village, Trowulan sub-district, Mojokerto has the potential to be used as an enrichment for teaching materials college subject for social education knowledge towards colleger taking S1 PGSD program, especially in the planned standard of ability/competence, which is to understand the social learning planning component with the main lesson planning component IPS education.

Keywords: Majapahit House; Education Facility; IPS fEducation PGSD

\section{Pendahuluan}

Salah satu peninggalan purbakala yang berupa bangunan rumah pada masa kerajaan Majapahit yang terbuat dari bahan kayu pada saat ini sudah tidak dapat dijumpai lagi yang disebabkan oleh karena bahan kayu jika dipergunakan untuk bahan bangunan tidak dapat bertahan lama dibandingkan dengan bangunan yang terbuat dari bahan batuan. Aspek normatif rekonstruksi rumah masa kerjaaan Majapahit yang seharusnya menjadi tradisi bagi generasi selanjutnya untuk bisa dimodernisasi telah hilang oleh budaya Eropa semenjak menjadi penjajah kolonial menguasai Nusantara(Rosyadi, Rozikin, \& Trisnawati, 2015). Benda-benda arkeologi berperan dan bermanfaat bagi pembangunan di bidang pendidikan, ilmu pengetahuan dan pariwisata, dapat pula berperan untuk menggambarkan kehidupan atau peradaban bangsa kita pada masa lalu melalui warisan bendabenda peninggalannya serta dari peninggalan itu dapat digunakan untuk menjaga dan melestarikan nilai-nilai luhur warisan budaya masa lalu itu yang pada akhirnya dapat membangkitkan dan meningkatkan kebanggaan serta jati diri sebagai bangsa. Peninggalan-peninggalan tersebut yang telah dilestarikann dan dikembangkan dapat bermanfaat untuk kepentingan akademis, ideologisstrategis dan kepentingan ekonomi-praktis (Muljana, 2005).

Rumah masa kerajaan Majapahit yang dibangun ulang atau direkonstruksi di Trowulan Mojokerto diharapkan dapat memberikan pembelajaran bagi generasi berikutnya khususnya para pelajar agar memiliki rasa kebanggaan bahwa kita juga merupakan bangsa yang besar dengan memiliki peradaban yang luhur. Peninggalan arkeologi memiliki peran dan fungsi yang sangat penting dalam proses pembangunan Bangsa kita, sejauh ini pelestariannya masih sangat kurang dengan kurangnya kebijakan pemerintah dalam bidang pembangunan belum memiliki wawasan pelestarian peninggalan, dengan banyaknya situs dan bangunan bersejarah yang tergusur oleh kepentingan pembangunan demi kebutuhan sektor ekonomi (Fatma \& Murwandani, 2014).

Peneliti tertarik meneliti rekonstruksi rumah masa kerajaan Majapahit yang telah dibangun kembali di desa Bejijong kecamatan Trowulan Mojokerto dari aspek sejarah sebagai media pembelajaran, khususnya mahasiswa Jurusan PGSD yang nantinya mengajar di sekolah, sebagai pengayaan bahan ajar Pendidikan IPS guna mencari jawab berbagai pertanyaan tentang apa, mengapa, dan bagaimana pengembangan kegiatan pembelajaran Pendidikan IPS khususnya mengenai rumah masa kerajaan Majapahit. Peneliti fokus pada permasalahan penelitian yang membatasi pada rekonstruksi rumah masa kerajaan Majapahit di desa Bejijong kecamatan Trowulan Mojokerto sebagai pengayaan bahan ajar mata kuliah pendidikan IPS bagi mahasiswa program S1 PGSD.

Para lulusan program PGSD diharapkan memiliki kompetensi diantaranya mampu mengembangkan materi pembelajaran IPS di SD yang diperoleh dari lingkungan terdekat peserta didik (kontekstual). mengembangkan satu kompetensi dasar menjadi materi pembelajaran yang inovatif dan sesuai dengan tingkat perkembangan usia peserta didik. Lulusan PGSD yang kelak menjadi guru hendaknya memiliki kemampuan untuk mengorganisasikan dan mengemas media 
pembelajaran sebagai materi IPS sehingga dapat memenuhi kebutuhan para peserta didik. Demikian pula kegiatan pengayaan bahan ajar dapat dipergunakan untuk berlatih dalam mengembangkan/mengemas media pembelajaran sebagai materi IPS. Kemampuan mengembangkan materi mencakup kemampuan menghimpun informasi (locating and gathering information)sebagai tahap awal dalam mengorganisasian materi pembelajaran. Kemampuan calon guru dalam mengemas materi pembelajaran yang kontekstual hendaknya memperhatikan potensi peserta didik atau respon siswa. Dengan demikian, pengembangan materi atau pengayaan bahan ajar bersifat induktif, yakni mulai dari dunia dan kebutuhan siswa.

\section{Metode Penelitian}

Lokasi penelitian dilakukan dibeberapa tempat yang berkaitan dengan objek penelitian dengan alasan untuk mendapatkan data yang benar-benar objektif. Lokasi yang telah peneliti tetapkan diantaranya:

1. Desa Bejijong kecamatan Trowulan Kabupaten Mojokerto.

2. Balai Pelestarian Cagar Budaya, Jalan Raya Trowulan Mojokerto

3. Candi Surowono di desa Surowono kecamatan Pare Kabupaten Kediri.

4. Candi Tegowangi di desa Tegowangi kecamatan Plemahan Kabupaten Kediri

5. Candi Penataran di desa Penataran kecamatan Nglegok kabupaten Blitar

6. Program Studi S-1 PGSD Universitas Wijaya Kusuma Surabaya

Waktu penelitian 1 Mei 2018 sampai dengan 5 Juli 2018. Pendekatan penelitian yang digunakan adalah pendekatan kualitatif yaitu berpikir secara induktif memandang masalah penelitian sebagai kasus yang bersifat mikro, kemudian ditarik dalam konteks yang lebih umum. Penelitian kualitatif ini diarahkan kepada usaha peneliti memberikan penjelasan secara luas dan mendalam serta orisinil tentang rekonstruksi rumah masa kerajaan Majapahit di desa Bejijong Kecamatan Trowulan kabupaten Mojokerto. Dan bertukar pikiran dengan narasumber secara lebih leluasa tentang masalah yang sedang diteliti. Paradigma penelitian kualitatif yang peneliti lakukan berlandaskan filsafat postpositivisme.

Jenis data dalam penelitian kualitatif terdiri dari data empiris dan data bermakna, data yang digunakan dalam penelitian ini adalah data empiris dimana data yang diperoleh di lapangan adalah data apa adanya tanpa mencari makna dibalik peristiwa maupun memanipulasi data.Jenis penelitian yang digunakan adalah studi kasus. Peneliti terlibat langsung dalam penelitian dan tidak diwakilkan, dalam pelaksanaan penelitian ini peneliti melakukan interaksi secara intensif dengan subjek penelitian. Dalam penelitian ini yang dimaksud data primer dan data sekunder, yaitu:

a. Data primer dalam penelitian ini lebih difokuskan pada rekonstruksi rumah masa kerajaan Majapahit di desa Bejijong kecamatan Trowulan Mojokerto. Data primer ini bersumber dari beberapa tempat yaitu dari Ketua RT, Perangkat Desa, Kepala Desa Bejijong, Tim Penggerak Kegiatan Rumah Majapahit, Petugas BPCB Trowulan.

b. Data sekunder dalam penelitian ini di peroleh dari dokumen/arsip, artefak, relief, modul Pendidikan IPS yang berkaitan dengan tema/judul penelitian ini. Yang termasuk sumber data sekunder: hasil rekaman, foto, hasil instrumen wawancara dengan Kaprodi dan Dosen PGSD Universitas Wijaya Kusuma Surabaya, dan dokumen

Cara untuk memperoleh data yang sesuai dengan masalah dalam penelitian ini, maka sumber data akan diperoleh dari:

1. Informan kunci, informan kunci dipilih dengan menggunakan teknik Nonprobability Sampling jenis purposive sampling dan snowball sampling. Informan dalam penelitian ini petugas BPCB Trowulan, Kepala Desa Bejijong, Perangkat Desa, Ketua TPK, dan masyarakat serta dosen mata kuliah Pendidikan IPS UWK Surabaya.

2. Peristiwa, yaitu berbagai peristiwa atau situasi sosial yang diobservasi dan berkaitan masalah atau fokus penelitian. Peristiwa-peristiwa yang diobservasi akan dikemukakan pada teknik pengumpulan data. Peristiwa yang terjadi yaitu telah dibangunnya rumah Majapahit di Desa Bejijong. 
3. Dokumen yang relevan dengan masalah dan fokus penelitian. Dokumen berupa foto-foto, gambar, laporan pembuatan rumah Majapahit, dan Rencana Pembelajaran Semester (RPS).

Peneliti menggunakan dua macam triangulasi sumber dan triangulasi teknik, trianggulasi sumber adalah trianggulasi yang digunakan untuk menguji kredibilitas data dengan cara mengecek data yang telah diperoleh melalui beberapa sumber. Dalam pengambilan data yang sama antara sumber informan yang satu dengan yang lain seperti dalam wawancara digunakan pertanyaan yang sama ditujukan kepada narasumber yang terdiri dari: (a) Ketua RT dan Ketua TPK Rumah Majapahit; (b) Kepala Desa Bejijong dan perangkatnya; (c) Kaprodi dan Dosen Pendidikan IPS UWKS.

Triangulasi teknik untuk menguji kredibilitas data dilakukan dengan cara mengecek data kepada sumber yang sama dengan teknik yang berbeda. Untuk menarik kesimpulan, data yang telah dikelompokkan disajikan dalam bentuk kalimat, yang difokuskan pada peran dosen mata kuliah Pendidikan ilmu pengetahuan sosial dalam meningkatkan pengayaan bahan ajar mata kuliah Pendidikan ilmu pengetahuan sosial di program studi PGSD melalui model pembelajaran sesuai dengan uraian seperti pada rumusan masalah yang akan diteliti yaitu, bagaimana rekonstruksi rumah masa kerajaan Majapahit di desa Bejijong kecamatan Trowulan Mojokerto berpotensi dijadikan sebagai pengayaan bahan ajar mata kuliah pendidikan IPS bagi mahasiswa program S1 PGSD khususnya pada standar kemampuan/kompetensi akhir yang direncanakan yaitu memahami komponen perencanaan pembelajaran dengan materi pokok komponen perencanaan pembelajaran IPS.

\section{Hasil dan Pembahasan}

Berdasarkan observasi lapangan dan wawancara dilapangan secara umum bentuk rumah masa kerajaan Majapahit beraneka ragam, salah satu bentuk rumah yang telah dipercaya oleh sebagian masyarakat adalah yang terdapat pada relief candi Minak Jinggo, selain itu juga terdapat bentuk rumah yang di Candi Penataran, Candi Surowono dan Candi Tegowangi. Penutup rumah Majapahit lebih banyak bentuknya joglo atau bentuk limas seperti yang bentuk rumah yang ada pada rumah-rumah di daerah Jawa Tengah dan Jawa timur sekarang. Lantai rumah masyarakat pada jaman kerajaan Majapahit diyakini berlantai tanah, sedangkan pada rekonstruksi rumah yang ada saat ini menggunakan lantai keramik mengikuti perkembangan jaman.

Tabel. 1 Rekonstruksi Rumah Majapahit

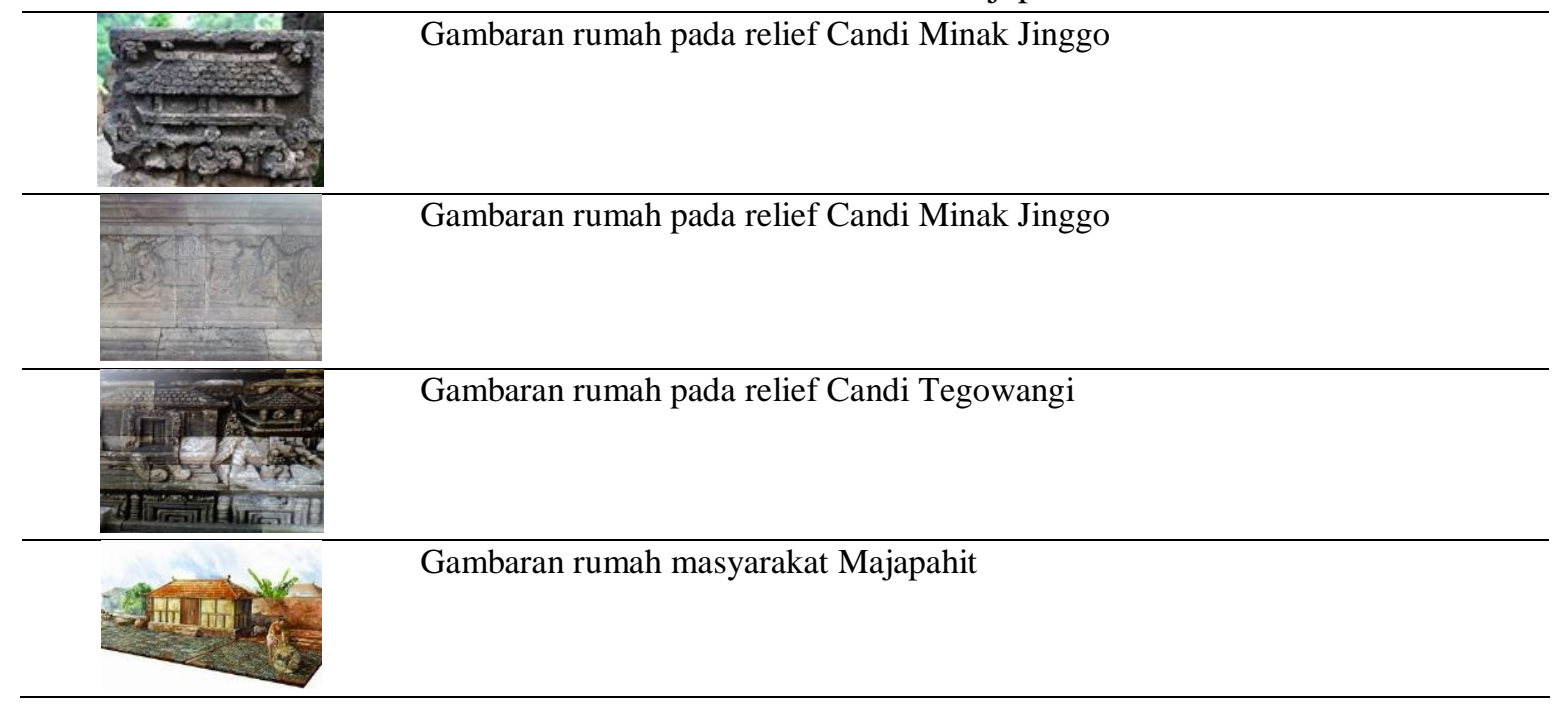




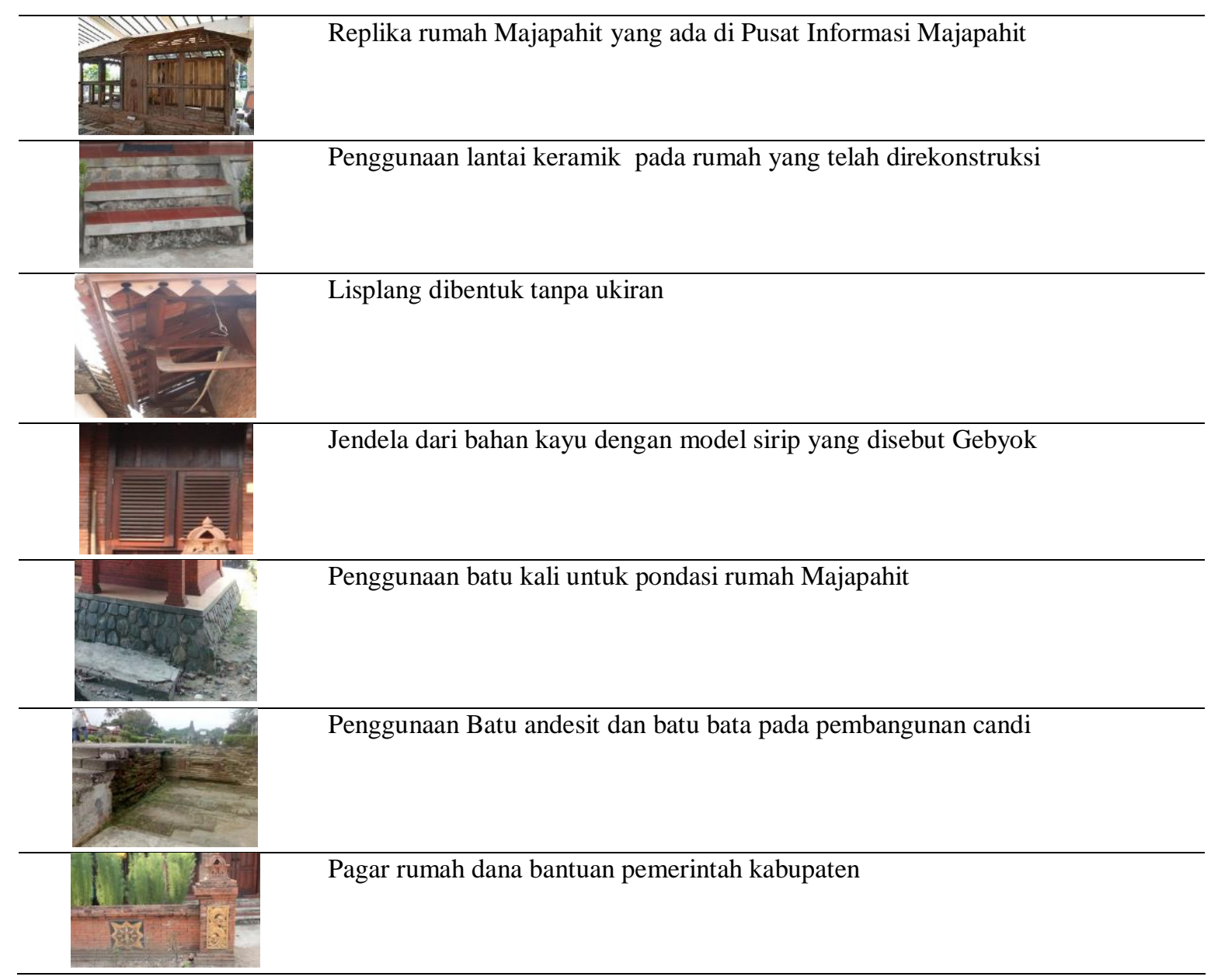

Dalam pembangunannya mengalami kendala akibat dari adanya isu yang berkaitan dengan SARA dan kabar kalau "rumah yang dibangun akan diminta kembali oleh pemerintah". Padahal bantuan tersebut berupa hibah murni. Namun akhirnya pembangunan rumah yang telah dibangun menjadi 197 unit. Diharapkan dengan dibangun rumah yang dipercaya sebagai salah satu bentuk rumah Majapahit dan dijadikan sebagai objek wisata budaya. Bentuk rumah yang telah direkonstruksi sudah sesuai dengan bentuk rumah masa Majapahit untuk masyarakat pada umumnya. Sedangkan bentuk rumah untuk para bangsawan Majapahit masih belum diketahui secara pasti, hal ini masih dalam tahap pengkajian oleh Balai Pelestarian Cagar Budaya (BPCB) Trowulan, bentuk rumahnya tidak seperti yang dibangun sekarang yang belum detil, dipercaya pula bangunan untuk bangsawan menggunakan ukir-ukiran.

Secara teoritis (Munandar, 2012) hasil penelitian beliau tentang "Pakuwon Pada Masa Majapahit: Kearifan Bangunan Hunian yang Beradaptasi dengan Lingkungan" disampaikan kajian ringkas ini berupaya untuk mengungkapkan bentuk-bentuk bangunan hunian masa Majapahit, berdasarkan data arkeologis dan sumber tertulis. Berdasarkan penggambaran relief terlihat hal yang menarik, yaitu bahwa bangunan-bangunan tersebut dikelilingi oleh pagar tembok, sehingga membentuk segugusan bangunan yang lazim dinamakan pakuwuan (pakuwon) yang merupakan kumpulan bangunan terbuka, setengah terbuka dan bangunan berbilik. Untuk menelusuri lebih lanjut berbagai bentuk Pakuwon masa Majapahit diperlukan sejumlah data yang masih dapat dipelajari hingga sekarang. Sebagaimana telah dikemukakan bahwa data arkeologis penting dalam telaah ini adalah berbagai bentuk relief yang menggambarkan bangunan hunian. Data relief tersebut ada yang 
masih menempel di dinding candi, dan ada pula yang telah lepas dari asosiasinya dengan media lain dan sekarang disimpan di Museum Pusat Informasi Majapahit, Trowulan.

Begitu pula hasil penelitian (Galestin, 1936) dikatakan terdapat bangunan kayu pada relief candi-candi di Jawa Timur, dijumpai bangunan-banguan yang diperkirakan sebagai tempat tinggal. Bangunan-bangunan tersebut mencakup bangunan empat tiang, bangunan enam tiang, bangunan delapan tiang dan bangunan tertutup. Jenis-jenis bangunan inilah yang ditelaah lebih lanjut untuk memperoleh gambaran mengenai bangunan tempat tinggal jaman Majapahit.

Rekonstruksi bangunan rumah yang dibuat didasarkan atas bukti yang ditemukan di situs dapat dilengkapi dengan perbandingan bentuk-bentuk rumah beserta unsur-unsurnya yang dapat kita lihat wujudnya dalam: (1) artefak sejaman seperti pada relief candi, model-model bangunan yang dibuat dan terakota, jenis-jenis penutup atap berbentuk genteng, sirap, bambu, ijuk: (2) rumah rumah sederhana milik penduduk sekarang di Trowulan; dan rumah-rumah di Bali. Lepas dari golongan status sosial penghuni rumah ini, ada hal lain yang menarik, yaitu penduduk Majapahit di Trowulan, atau setidak-tidaknya penghuni rumah ini, telah dapat menggabungkan antara segi fungsi dan estetika. Halaman rumah ditata sedemikian rupa untuk menghindari genangan air dengan cara diperkeras dengan krakal bulat dalam bingkai bata. Di sekeliling bangunan terdapat selokan terbuka dengan bagian dasarnya berlapis bata untuk mengalirkan air dari halaman. Dilengkapi juga dengan sebuah jambangan air dan terakota yang besar, dan kendi terakota berhias. Gambaran seperti ini rupanya semacam taman pada halaman rumah. Di sebelah timur ada beberapa struktur bata yang belum berhasil diidentifikasi. Mungkin rumah yang ukurannya relatif kecil ini hanya merupakan salah satu dan kompleks bangunan rumah yang berada dalam satu halaman seluas 200-an meter persegi, dikelilingi oleh pagar seperti rumah-rumah di Bali.

Karya Mpu Prapanca tentang Kakawin Nagarakretagama disebutkan tentang "rumah" pada pupuh VIII-XII diketahui Kerajaan Majapahit selain merupakan ibu kota sebagai pusat pemerintahan dan tempat kedudukan raja juga tempat para pejabat kerajaan. Ditinjau dari konsep kosmologi, wujud ibu kota Majapahit dianggap sebagai perwujudan jagad raya, sedangkan raja identik dengan dewa tertinggi yang bersemayam di puncak Gunung Mahameru (Semeru). Disebutkan pula bahwa susunan bangunan di istana meliputi tempat tinggal raja dan keluarganya, lapangan manguntur, pemukiman para pendeta, dan rumah-rumah jaga pegawai kerajaan. Rumah di dalam istana indah, bagus, dan kuat. Ibu kota Majapahit dikelilingi oleh raja-raja daerah dan kota-kota lain. Di sekitar istana tempat kedudukan raja terdapat tempat-tempat kedudukan raja-raja daerah (paduka bhatara) serta para pajabat/pembesar kerajaan. Kesan kerajaan yang memiliki kekuatan dan kekuasaan yang sangat luas dengan ditunjukkan adanya bentuk istana dan bangunan lainnya yang memiliki corak yang indah dan teknik pembangunan yang tentunya sudah menggunakan teknologi yang lebih modern dijamannya.

Berdasarkan paparan di atas dapat peneliti temukan beberapa hasil temuan penelitian yang berkaitan dengan bentuk rumah Majapahit hasil rekonstruksi. Bentuk rumah masa kerajaan Majapahit beraneka ragam, salah satu bentuk rumah yang telah dipercaya oleh sebagian masyarakat adalah yang terdapat pada relief candi Minak Jinggo seperti pada terakota, dengan penutup rumah mulai dari genteng bentuk limas/joglo seperti rumah-rumah di Jawa Tengah dan Jawa Timur sampai pondasi, tembok dengan menggunakan batu bata merah yang terlihat hanya ditata rapi, tetapi dalam penyusunannya diberi semen. Rangka bangunan dipergunakan bahan cor yang didalamnya terdapat rangkaian besi yang dicor mengunakan semen, pasir dan koral sebagai penguat mulai dari bagian pondasi, tiang tertutup oleh batu bata merah. Batu bata yang dibuat sekarang ukurannya lebih kecil bila dibandingkan dengan batu bata yang lama ukurannya lebih besar. Jendela yang dipasang sebelah kiri dan kanan serta pintu yang terbuat dari bahan kayu dengan disusun miring di bagian atas pintu 
dan jendela. Genting menyerupai bentuk jaman Majapahit dahulu, lantainya dahulu berupa alas tanah, sedangkan sekarang menggunakan keramik.

Jika dibanding dengan rumah di Bali bahan yang banyak dipergunakan yaitu kayu, seperti yang ada di museum dan bentuk-bentuknya juga sama sedang yang dibangun di desa Bejijong dilihat dari bahannya sudah banyak yang menyimpang. Selain di Trowulan terdapat pula di Wonosalam juga sudah terlebih dahulu terdapat Kampung Jawi dibangun rumah Majapahit dijadikan objek wisata budaya. Sebagian masyarakat yang paham bahwa pembangunan itu dianggap sebagai warming-up dari pemerintah dengan harapan supaya masyarakat selanjutnya dapat mengembangkan program desa wisata serta diharapkan oleh masyarakat akan adanya sebuah lahan khusus pembangunan rumah Majapahit yang didesign sesuai pakemnya. Serta masyarakat berharap pemerintah melakukan risetriset lanjutan yang berkaitan dengan kajian-kajian rumah Majapahit, dimana masyarakat ingin mengangkat kembali kebesaran dan kejayaan Majapahit di Indonesia.

Rekonstruksi rumah Majapahit versi BPCB hasil reka ulang Osriful Oesman seorang ahli arkeolog dan arsitektur keterangannya kurang lengkap tentang rumah Majapahit kecuali bila rumah tersebut dibenahi terlebih dahulu dan diberi tulisan "rumah Majapahit strata sdra" bentuk rumah masyarakat paling bawah/rendah. perlu dijelaskan bahwa rumah itu adalah rumah masyarakat pada umumnya dan berbanding terbalik dengan kebesaran Majapahit yang dapat membunuh karakter Majapahit. Masyarakat sangat senang dengan dibangunnya rumah Majapahit di desa Bejijong, dari rumah itu mereka berharap ada kemajuan dan peningkatan dalam bidang ekonomi masyarakat dengan dijadikan rumah tersebut sebagai home stay, Kerajinan cor kuningan dan batik "Surya Majapahit" dapat menjadi daya Tarik wisatawan baik lokal maupun domestik serta meningkatkan kunjungan pariwisata sebagai destinasi wisata budaya.

Tabel 2. Pemanfaat Rekonstruksi Rumah Majapahit

\begin{tabular}{l}
\hline \\
\hline
\end{tabular}

Dengan dibangunnya rumah Majapahit dapat menggugah kesadaran masyarakat yang selama ini terkikis cerita tentang kebesaran Majapahit, menjadi pengingat dan memberi semangat akan kekuatan Majapahit yang dapat mempersatukan Nusantara. Permendikbud Nomor 65 Tahun 2013 tentang Standar Proses Pendidikan Dasar dan Menengah menetapkan bahwa perencanaan pembelajaran dirancang dalam bentuk Silabus dan Rencana Pelaksanaan Pembelajaran (RPP), penilaian proses pembelajaran menggunakan pendekatan penilaian otentik (authentic assesment) 
yang menilai kesiapan siswa, proses, dan hasil belajar secara utuh. Pelaksanaan pembelajaran juga melaksanakan program remedial dan program pengayaan.

Peraturan Menteri Pendidikan dan Kebudayaan Nomor 22 Tahun 2016 Tentang Standar Proses Untuk Satuan Pendidikan Dasar dan Menengah dijelaskan diantara prinsip pembelajaran yang digunakan yang sesuai dengan Standar Kompetensi Lulusan dan Standar salah satunya yaitu guru sebagai satu-satunya sumber belajar menjadi belajar berbasis aneka sumber belajar. Sumber belajar idak hanya berpaku pada penggunaan buku teks pelajaran saja, namun dapat diperkaya dengan penggunaan media-media pembelajaran maupun bahan ajar yang lain. Dalam kurikulum 2013 dirumuskan secara jelas kompetensi inti (KI) dan kompetensi dasar (KD) yang harus dikuasai peserta didik. Penguasaan KI dan KD setiap peserta didik diukur dengan menggunakan sistem penilaian acuan kriteria (PAK). Jika peserta didik mencapai standar tertentu maka peserta didik tersebut dipandang telah mencapai ketuntasan. Oleh karena itu program pengayaan dapat diartikan memberikan tambahan/perluasan pengalaman atau kegiatan peserta didik yang teridentifikasi melampaui ketuntasan belajar yang ditentukan oleh kurikulum. Dalam program pengayaan, media belajar harus betul-betul disiapkan pendidik agar dapat memfasilitasi peserta didik dalam menguasai materi yang diberikan.

Berdasarkan Permendikbud No.22 Tahun 2016 pada dasarnya menganut sistem pembelajaran berbasis aktivitas atau kegiatan, kompetensi, sistem pembelajaran tuntas, dan sistem pembelajaran yang memperhatikan dan melayani perbedaan individual peserta didik. Dengan memperhatikan prinsip perbedaan individu (kemampuan awal, kecerdasan, kepribadian, bakat, potensi, minat, motivasi belajar, gaya belajar) tersebut, maka program pengayaan dilakukan untuk memenuhi kebutuhan/hak anak. Dalam program pengayaan, guru/dosen memfasilitasi peserta didik untuk memperkaya wawasan dan keterampilannya serta mampu mengaplikasinya dalam kehidupan sehari-hari. Teori tentang pengayaan yang disampaikan (Muktar \& Rusmini, 2005) diyatakan bahwa kegiatan pengayaan merupakan kegiatan yang relatif bebas, karena bersifat memperluas, memperdalam, dan menunjang satuan pelajaran yamg diterapkan kepada para siswa yang sudah mastery (tuntas) dalam belajar. Artinya kegiatan pengayaan ini bukanlah suatu kasus yang pelik sebagaimana kegiatan perbaikan yang dialami oleh siswa siswa yang belum mastery, yang disebabkan oleh kelambatan, kesulitan atau kegagalan dalam belajar. Kegiatan pengayaan ini ada dua macam, yaitu:

1. Pengayaan horizontal yaitu upaya pemberian tugas sampingan yang akan memperkaya pengetahuan siswa mengenai materi yang sama, karena dalam suatu kelas, siswa dan temantemannya yang memiliki perbedaan tingkat pengetahuan, mungkin akan merasa bosan atau jenuh bila seorang guru tetap menerangkan bahan yang sudah di kuasainya.

2. Pengayaan vertikal yaitu kegiatan pengayaan yang berupa peningkatan dari tingkat pengetahuan yang sedang diajarkan ke tingkat yang lebih tinggi yang akan diajarkan, sehingga siswa maju dari satuan pelajaran yang sedang diajarkan kesatuan pelajaran berikutnya menurut kemampuan dan kecerdasanya sendiri.

Bahan ajar sebagai perangkat materi atau substansi pembelajaran (teaching material) yang disusun secara sistematis, menampilkan sosok utuh dari kompetensi yang akan dikuasai siswa dalam kegiatan pembelajaran. Bahan ajar memungkinkan siswa dapat mempelajari suatu kompetensi atau $\mathrm{KD}$ secara runtut dan sistematis sehingga secara akumulatif mampu menguasai semua kompetensi secara utuh dan terpadu. Peninggalan arkeologi memiliki nilai yang tinggi sebagai sumber bahan ajar bagi semua lapisan masyarakat dan semua tingkat pendidikan. Melalui penelitian arkeologi dapat diperoleh bahan pendidikan tentag sejarah dan nilai-nilai luhur kebudayaan serta kejayaan bangsa 
pada masa lalu. Selain itu melalui arkeologi juga diperoleh bahan pendidikan mental spiritual dengan membangkitkan kesadaran dan kebanggaan akan sejarah peradaban bangsa, sekaligus memperkokoh kepribadian dan jati diri. Peneliti telah berupaya menelaah bahan pustaka yang ada sebagai hasil kajian demi kelengkapan dan keadaan di lapangan yang didapatkan dari berbagai sumber informan yang ada kaitan rekonstruksi rumah masa kerajaan Majapahit dengan bahan ajar mata kuliah pengetahuan IPS.

Dari hasil pemaparan data diatas yang berkaitan dengan pengayaan bahan ajar baik yang peneliti dapatkan dari masyarakat desa Bejijong, perangkat desa maupun para pemangku kepentingan rekonstruksi rumah Majapahit, juga dari kalangan akademisi yang mengajar di Universitas Wijaya Kusuma Surabaya.

Adapun temuan yang peneliti dapatkan belum pernah diajarkan disebabkan dosen mengajar di wilayah kota Surabaya, sehingga pembelajaran dikaitkan dengan hal-hal yang terjadi dan dijumpai di Surabaya yang lebih kontekstual. Sehingga dalam penugasan terhadap mahasiswa juga tidak pernah menyangkut tentang rumah Majapahit. Namun bahan pembelajaran tentang rekonstruksi rumah Majapahit untuk semester yang akan datang menjadi bahan pemikiran dan ide yang sangat menarik. Perlunya mahasiswa memiliki pengalaman terkait dengan sejarah sehingga tidak hanya teori saja, pembelajaran lebih mudah dipahami atau lebih mementingkan pengalaman secara real sehingga pembelajarannya long life education. Selama ini pembelajaran IPS itu hanya teori dan jarang sekali mengkaitkan dengan lingkungan sekitar atau kearifan lokal dengan melaksanakan observasi langsung mengenai Majapahit akan mendapatkan pembelajaran secara riil dan meningkatkan motivasi belajarnya.

Rekonstruksi rumah Majapahit belum diajarkan maupun ditugaskan dalam perkuliahan di program studi S-1 PGSD, namun diperlukan proses dan waktu yang cukup panjang agar rumah Majapahit dapat dijadikan pengayaan bahan ajar, serta diperlukan pula sosialisasi yang masif oleh berbagai pihak, baik pemerintah, dinas terkait serta peran pendidik. Berdasarkan hasil temuan diatas dapat disimpulkan sebagai berikut: Rekonstruksi rumah Majapahit di desa Bejijong Kecamatan Trowulan Mojokerto merupakan bentuk penggugah semangat masyarakat Indonesia akan kebesaran suatu bangsa dari sejarah di masa lampau, yang dapat dijadikan sebagai pengayaan bahan ajar baik di pendidikan tingkat dasar sampai perguruan tinggi, walaupun bentuk rumah yang ditampilkan belum mencerminkan secara utuh rumah Majapahit disebabkan banyaknya bentuk rumah yang beraneka ragam berdasarkan tingkat/strata masyarakat Majapahit. Rekonstruksi rumah masa kerajaan Majapahit di desa Bejijong kecamatan Trowulan Mojokerto sangat berpotensi untuk dijadikan pengayaan bahan ajar mata kuliah pendidikan IPS bagi mahasiswa program S1 PGSD khususnya pada standar kemampuan / kompetensi akhir yang direncanakan yaitu memahami komponen perencanaan pembelajaran IPS dengan materi pokok komponen perencanaan pembelajaran IPS.

Bentuk rumah masa kerajaan Majapahit beraneka ragam, salah satu bentuk rumah yang telah dipercaya terdapat pada relief candi Minak Jinggo, terdapat bentuk rumah pada relief Candi Penataran, Candi Surowono dan Candi Tegowangi. Penutup rumah Majapahit lebih banyak bentuknya joglo atau bentuk limas seperti yang bentuk rumah yang ada pada rumah-rumah di daerah Jawa Tengah dan Jawa timur sekarang. Lantai rumah masyarakat pada jaman kerajaan Majapahit diyakini berlantai tanah, sedangkan pada rekonstruksi rumah yang ada saat ini menggunakan lantai keramik mengikuti perkembangan jaman. Bentuk rumah yang telah direkonstruksi sudah sesuai dengan bentuk rumah masa Majapahit untuk masyarakat pada umumnya. Sedangkan bentuk rumah untuk para bangsawan Majapahit masih belum diketahui secara pasti, hal ini masih dalam tahap pengkajian oleh Balai Pelestarian Cagar Budaya (BPCB) Trowulan, bentuk rumahnya tidak seperti 
yang dibangun sekarang yang belum detil, dipercaya pula bangunan untuk bangsawan menggunakan ukir-ukiran.

Proses rekonstruksi mengalami kendala akibat dari adanya isu yang berkaitan dengan SARA dan isu "rumah yang dibangun akan diminta kembali oleh pemerintah". Padahal bantuan tersebut berupa hibah murni. Pada akhir rekonstruksi rumah yang telah dibangun menjadi 197 unit dari rencana tahap I sebanyak 90 unit dan tahap II sebanyak 94 unit. Rekonstruksi rumah Majapahit diharapkan dapat dijadikan sebagai objek wisata budaya.

Dasar rekonstruksi bangunan rumah yang dibuat didasarkan atas bukti yang ditemukan di situs dapat dilengkapi dengan perbandingan bentuk-bentuk rumah beserta unsur-unsurnya belum sepenuhnya dapat menunjukkan rumah Majapahit secara utuh. Rekonstruksi rumah Majapahit dianggap sebagai warming-up dari pemerintah dengan harapan supaya masyarakat dapat mengembangkan program desa wisata serta diharapkan oleh masyarakat akan adanya sebuah lahan khusus pembangunan rumah Majapahit yang didesign sesuai pakemnya. Serta masyarakat berharap pemerintah melakukan riset-riset lanjutan yang berkaitan dengan kajian-kajian rumah Majapahit, dimana masyarakat ingin mengangkat kembali kebesaran dan kejayaan Majapahit di Indonesia(Umamah, Sumardi, \& Wahyuni, 2017).

Rekonstruksi rumah Majapahit versi BPCB hasil reka ulang dianggap masih kurang lengkap tentang rumah Majapahit kecuali bila rumah tersebut dibenahi terlebih dahulu dan diberi tulisan "rumah Majapahit strata sudra" bentuk rumah masyarakat paling bawah/rendah. Perlu dijelaskan bahwa rumah itu adalah rumah masyarakat pada umumnya dan berbanding terbalik dengan kebesaran Majapahit yang dapat membunuh karakter Majapahit. Masyarakat desa Bejijong sangat senang dengan dibangunnya kembali rumah Majapahit di desanya, dari rumah itu mereka berharap ada kemajuan dan peningkatan dalam bidang ekonomi masyarakat dengan dijadikan rumah tersebut sebagai home stay, Kerajinan cor kuningan dan batik "Surya Majapahit" dapat menjadi daya Tarik wisatawan baik lokal maupun domestik serta meningkatkan kunjungan pariwisata sebagai destinasi wisata budaya dan dapat menggugah kesadaran masyarakat yang selama ini terkikis cerita tentang kebesaran Majapahit, menjadi pengingat dan memberi semangat akan kekuatan Majapahit yang dapat mempersatukan Nusantara.

\section{Simpulan}

Dalam pembelajaran mata kuliah Pendidikan IPS di program studi PGSD belum pernah diajarkan mengenai rumah Majapahit dalam proses belajar mengajar mata kuliah pendidikan IPS harus kontekstual, karena peniliti mengambil data di sebuah perguruan tinggi yang ada di kota Surabaya, sehingga pembelajaran dikaitkan dengan hal-hal yang terjadi dan dijumpai di Surabaya. Begitu pula dalam penugasan terhadap mahasiswa juga tidak pernah menyangkut tentang rumah Majapahit. Namun bahan pembelajaran tentang rekonstruksi rumah Majapahit menjadi bahan pemikiran yang sangat menarik untuk dijadikan bahan ajar diperkuliahan.

Mahasiswa PGSD perlu juga memiliki pengalaman terkait dengan sejarah sehingga tidak hanya teori saja, dengan terjun langsung di lapangan akan menjadikan penguasaan bahan ajar dan meningkatkan motivasi belajar lebih mudah dipahami karena selama ini pembelajaran IPS itu hanya teori dan jarang sekali mengkaitkan dengan lingkungan sekitar atau kearifan lokal. Dengan belum diajarkan maupun ditugaskan dalam perkuliahan di program studi S-1 PGSD, perlu disosialisasikan dan ditetapkan dalam proses pembelajaran.

Dengan demikian secara garis besar rekonstruksi rumah Majapahit di desa Bejijong kecamatan Trowulan Mojokerto sangat potensial untuk dijadikan pengayaan bahan ajar dalam perkuliahan mata kuliah Pendidikan IPS di program studi S-1 PGSD khususnya pada standar kemampuan/kompetensi akhir yang direncanakan yaitu memahami komponen perencanaan pembelajaran IPS dengan materi pokok komponen perencanaan pembelajaran IPS dalam proses pembelajaran secara masif. 


\section{Daftar Pustaka}

Fatma, D., \& Murwandani, N. G. (2014). Tinjauan Visual pada Terakota Koleksi Museum Majapahit, Trowulan, Kabupaten Mojokerto. Jurnal Pendidikan Seni Rupa, 2(3), 64-73.

Galestin, T. P. (1936). Houtbouw op Oost-Javaansche Tempelreliefs. (M. Nijhoff, Ed.). s'Gravenhage.

Muktar, M., \& Rusmini, R. (2005). Pengajaran Remedial. Jakarta: Nimas Multima.

Muljana, S. (2005). Menuju puncak kemegahan : sejarah kerajaan Majapahit. Yogyakarta: LKiS.

Munandar, A. A. (2012). Pakuwon Pada Masa Majapahit: Kearifan Bangunan Hunian yang Beradaptasi dengan Lingkungan. In International Conferenceon Indonesian Studies (pp. 3652).

Rosyadi, K., Rozikin, M., \& Trisnawati. (2015). Analisis Pengelolaan Dan Pelestarian Cagar Budaya Sebagai Wujud Penyelenggaraan Urusan Wajib Pemerintahan Daerah (Studi pada Pengelolaan dan Pelestarian Situs Majapahit Kecamatan Trowulan Kabupaten Mojokerto). Jurnal Administrasi Publik, 2(32), 830-836.

Umamah, N., Sumardi, S., \& Wahyuni, E. S. (2017). Pengembangan Cerita Sejarah Gayatri Sri Rajapatni Perempuan Pembangun Imperium Majapahit Pada Mata Pelajaran Sejarah SMA. Jurnal Pendidikan Dan Humaniora, 55(1), 63-68. 